\title{
An Investigation of the Role of Legends and Storytelling in Early Childhood Practices in a Kanien'kehá:ka (Mohawk) Early Childhood Facility
}

\begin{abstract}
Sandra Deer
McGill University

Author Note

Correspondence concerning this article should be addressed to sandra.deer@mail.mcgill.ca or sdstandup@hotmail.com

Abstract

Through the course of Indigenous history, cultural and spiritual knowledge remains, in many places as faint as the smoke rising from the embers of last night's fire; in other places, with enough flame to ignite another log. In spite of the genocidal acts portrayed through colonialism's experimentation through religious doctrine, residential school, legislation, treaties broken and unbroken, reservations, and spiritual disregard, the Indigenous peoples of Turtle Island remain living, breathing and believing that their history is alive through the oral stories of their beginnings and endings. Indigenous education can only be defined through the culture of the people themselves. Historical Indigenous education was transferred orally for thousands of years with very little disruption or inconsistencies; therefore distinct meanings and connections were continuously addressed through one's lifetime through the wisdom of elder's legends and stories. The investigation of the role of legends and storytelling in an early childhood setting in Kahnawa:ke, Quebec is portrayed through a combination of research literature, classroom observations and personal interviews documented as portraiture. The main finding was that cultural legends and stories familiar to historical, ceremonial and spiritual practices are vital to the cultural foundation of the Haudenosaunee (peoples of the longhouse or the Iroquois) and Kahnawake'hró:non (people of Kahnawa:ke).
\end{abstract}

Keywords: Kanien'kehá:ka (Mohawk); ECE; early childhood education; cultural legends and stories; residential schools; storytelling
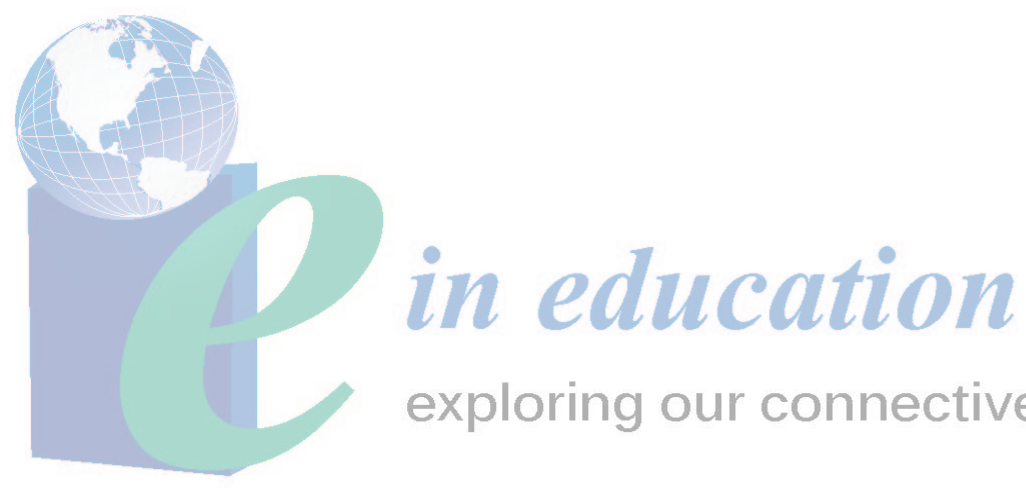


\section{An Investigation of the Role of Legends and Storytelling in Early Childhood Practices in a Kanien'kehá:ka (Mohawk) Early Childhood Facility}

Indigenous peoples have every right to celebrate their continued existence, and to draw strength from the fact that their nations live on despite the terrible losses of the past 500 years. (Alfred, 1999, p. 33)

Indigenous peoples of the world have taught and learned through oral transference of knowledge for thousands of years. Current definitions of educational tools used to transfer cultural knowledge are today known or referred to as culturally based education, culturally relevant curriculum, and most pertinently, Indigenous education. Indigenous communities around the world have been working diligently to stem the multi-generational effects of residential schooling and foreign governing policies within Native/Aboriginal territories (Faries, 2004; McKeough et al., 2008). Promoting cultural knowledge's has become and essential foundation in revitalizing language, cultural practices, history and ceremony and song. The fluidity of the continuous traditions of storytelling combined with contemporary knowledge can provide the strength to sustain and regain what was and has been the original ways of knowing, learning and teaching (Archibald, 2001; Ho'omanawanui, 2010).

\section{Methodology}

The realities of Indian belief and existence have become so misunderstood and distorted at this point that when a real Indian stands up and speaks the truth at any given moment, he or she is not only unlikely to be believed, but will probably be contradicted and "corrected" by the citation of some non-Indian and totally inaccurate "expert." (Rains, Archibald, \& Deyhle, 2000)

\section{Indigenous Research Knowledge}

Knowledge varies from age, gender, race, geographical region, and unfortunately economic status. In Research as Resistance, Kovach (2005) writes about research methodologies and their relation to the silencing and absenteeism of voice from marginal societies, which she finds very disturbing (p. 21). Smith (1999) agrees that "Indigenous voices have been overwhelmingly silenced" and that Indigenous scholars struggle to write, theorize and research (p. 29).

Wilson (2001) explains that a dominant research paradigm is built on the belief that knowledge is an individual entity that can be gained and owned, whereas an Indigenous paradigm focuses on the belief that "knowledge is relational" and "shared with all of creation" (p. 177). He goes on to say that "Indigenous people need to do Indigenous research because we have the lifelong learning and relationship that goes into it. You are not just gaining information from people; you are sharing your information" (Wilson, 2001, p. 179).

The research procedure I chose to follow is situated within qualitative research. According to Creswell (2009), "Qualitative procedures rely on text and image data and has unique steps in data analysis, and draw on diverse strategies of inquiry" (p. 173). The qualitative approach I chose to examine my data was "constant comparative analysis" (Creswell, 2009, p. 13). This approach was best suited for my study because it helped "generate explicit categories[,] which can help to provide an understanding of the data" (Grove, 1988, p. 277), thereby, creating ample opportunity to bridge all data as relational. 
The interviewing protocol I followed was a semi-structured protocol. This protocol fit my research because it allowed me to follow a set of prompts and provided room to ask follow-up questions that may develop during the interview (Brenner, 2006). This type of interviewing mirrors reciprocity between interviewer and interviewee and creates a relational dialogue. I audio recorded the interviews because, according to Brenner (2006), "an audiotape recording allows an interviewer to focus on the conversation with an informant and carries a more complete record of the informant's actual words" (p. 365).

My goal in the research was specifically to investigate cultural stories and legends and how they are currently used in an ECE classroom; my research involved three classrooms of 18month to 4-year-old children: three teachers, 49 children, two parents, one grandparent, and two program administrators. My method combined interviews with classroom observations as well as teacher discussion of curriculum materials and artifacts. Classroom observations were scheduled after signed parent consent. Interviews were conducted in the April 2013. The research site is an early childhood facility located in Kahnawa:ke, Quebec. This facility is the largest center on the reserve that offers daycare services and preschool education as a stepping stone for Kindergarten. There are nine classrooms at this facility.

This article was developed through the findings of a Master's thesis. The content was selected carefully with the intent of having readers gain insight and understanding of the research and its significance to maintaining and or reviving Indigenous cultural knowledge in an early childhood educational setting. The main questions surrounding the research were as follows: "What role do cultural stories and legends play in early childhood education? Are cultural stories/legends an important part of Kanien'kehá:ka (people of the Flint) culture and identity? Do these stories/legends have any relevance to children's learning? What are some of the goals behind implementing legends through the curriculum?

\section{Indigenous Storytelling}

Each individual story is powerful. But the point about the stories is not that they simply tell a story, or tell a story simply. These new stories contribute to a collective story in which every indigenous person has a place. (Smith, 1999, p. 144)

Prior to the unexpected arrival of European travelers, the continents now known as North and South America were occupied with its original people who lived and died within a specific cultural pattern that resonated with meaning and understanding of who they were as a society of human beings. Cultural beliefs were practiced, spoken, danced, sang, mourned, taught, and dreamt by the people. Their ideology shaped the culture of society and maintained a structure that was reciprocal from one generation to the next. This reciprocity was the practice of storytelling or legends. Indigenous nations used storytelling and legends as an educational tool to promote cultural values, knowledge, and identity (Archibald, 2001; Kanu, 2006; Kirkness, 1995). The story or legend was comprised of those values that reflected identity and the relationship with the environment and the animal world (Antone \& Córdoba, 2005; Friesen \& Friesen, 2007a; Duryea LeBaron \& Potts, 1993; Lutz \& Moritz-Arndt, 1995). This form of transference was an important tool specific to the continuity of the culture of that nation (Armstrong, 1987; Faries, 2004; Ho'omanawanui, 2010; Kanu, 2006; McKeough et al., 2008). Providing culturally relevant education through storytelling and legends familiar to that nation 
helps create a connection to their cultural past in the present (Pence, Rodriquez de France, Greenwood \& Pacini-Ketchabaw, 2007).

Historically, storytellers were mainly elders, but others, who were talented and skilled, were also important in the continuity of this oral transference. These stories or legends provided much more than local knowledge; they transferred the history of the land and the people, songs, ceremonies, entertainment, and spiritual guidance. Educating in this fashion consisted of close bonded interactions between all community members (Antone \& Córdoba, 2005). In The Sacred Hoop, Gunn Allen (1992) states:

American Indian myth is a story that relies preeminently on symbol for its articulation. It generally relates a series of events and uses supernatural, heroic figures as the agents of both the events and the symbols. As a story, it demands the immediate, direct participation of the listener. (p. 105)

\section{The Kanien'kehá:ka}

The Kanien'kehá:ka (people of the Flint) are one of the Six Nations of the Iroquois, also known as the Haudenosaunee (people of the longhouse). Prior the $17^{\text {th }}$ century, there were only five nations that made up this Confederacy of Nations. The Tuscarora Nation was the last nation to unite the Six Nations peoples (Wallace, 1994). As a confederacy of nations, the Haudenosaunee (peoples of the longhouse) share a common system of beliefs and practices that have sustained their unity for centuries. The formation of the Confederacy was founded on Kaianere'kó:wa (Great Law of Peace). Haudenosaunee (people of the longhouse) political culture derived from these teachings of peace and diplomacy. Through many oral teachings is manifest the connection and validity of Haudenosaunee existence here on Mother Earth.

\section{Indigenous Ways of Knowing and Teaching}

Because we are old, it may be thought that the memory of things may be lost with us, who have not, like you, the art of preserving it by committing all transactions to writing. We nevertheless have methods of transmitting...an account of all these things. You will find the remembrance of them is faithfully preserved, and our succeeding generations are made acquainted with what has passed, that it may not be forgot as long as the earth remains. (Kanickhungo, Haudenosaunee spokesperson, 1736 as cited in Rains, Archibald, \& Deyhle, 2000, p. 337)

Indigenous ways of knowing and teaching have always stood in contrast to Eurocentric ideological perspectives on all matters concerning land, cultural/religious practices, government, and education. However long and hard the struggles were and continue to be, Indigenous communities now take a more active role in their education in order to preserve and promote a strong and balanced foundation for the continuity of cultural identity (Friesen \& Friesen, 2007b; Ho'omanawanui, 2010). For many Indigenous nations, the coming of organized religion, separate governing systems and particularly education "is considered the time of greatest oppression, a period of cultural disruption marked by efforts of assimilation[,] which today are viewed more as tactics of extermination" (Kirkness, 1995, p. 30).

For decades, the challenges of reconstructing mainstream education to suit and identify with Indigenous culture have been extremely exhausting for those on the front lines of education and its policies. Reports upon reports have been made, identified, released, and then filed, in 
regard to the immediate needs of Indigenous communities and their education system. A common result of these studies/reports is the lack of materials relevant to Aboriginal culture (Kirkness, 1995; Kanu, 2006), which is needed to create and deliver curriculum that is knowledgeable about and responsive to the students' cultural background and current community ideology.

In a YouTube video, Dr. Taiaiake Alfred (2010) speaks about the loss of traditional ways of knowing who one is and how that loss reflects many current community situations. He says that Indigenous education is a revolutionary act and a resurgence of indigeneity. He also explains that if one does not have the tools to pass on to the young people, then what will they have to work with; one is not going to solve their problems, but one can give them the tools, because the tools they now have are very poor. He goes on to say that the cultural foundation that the ancestors stood on to confront the challenges that they faced was huge, like a large rock, and that was their language, cultural knowledge, ceremonial engagement, social connections, and spirituality.

Today, Indigenous education is interwoven through various subject courses such as Native Studies, History of Aboriginal peoples, Native languages, Native Literature and Poetry, Native American Medicines, and so forth. Wilson and Wilson (2002) state that the more we articulate what an Indigenous perspective is and the more we clearly express our worldview, the more difficult it is for it to be accepted and understood by academia (p. 67). Hill (2002) reminds us that there are many hurdles in Indigenous education and at the very forefront there is the need to identify "exactly what it is, or what we want it to be" (p. 282). She goes on to say that we need to design systems and methods with unique delivery and convince our own people that it is viable and will prepare our children for the world out there (Hill, 2002).

\section{Residential Schools}

The arrival and establishment of European culture has heralded in some ways the beginning of the end of Indigenous, Native, or Aboriginal ancestral life ways (Faries, 2004; Kirkness 1995; Antone \& Córdoba, 2005; Ho'omanawanui, 2010; Kanu, 2006). Over the centuries, European settlers have bestowed upon themselves the privilege to lay claim to land that does not belong to them and the right to exert dominance over the lives and cultures of the Indigenous peoples they encountered. Residential schools are only one of the foreign systems enforced on Indigenous peoples, but mark the most destructive and tragic disruption of an entire culture of people (Faries, 2004).

Residential schools have had very little benefit for Indigenous children and their families. Recent documentation and personal accounts have provided evidence of the abuse and trauma that occurred under these so-called "educational facilities" for Indigenous children. Historical documentation offers limited information on the children who attended residential schools and in regards to the events that occurred; what is available is presented "from the perspective of the government or the missionaries whose policies controlled them" (Haig-Brown, 1988, p. 25).

Today, both church and government and Indigenous peoples reflect their own perspective and carry the burden of guilt and shame of what had occurred within these government and church facilities whose goal was to "educate the Indian." Results of these policies have been long buried in the hearts, minds, and spirits of those who were once children of residential schools. Rebuilding education through decolonizing methods, for example by using storytelling to recite 
our histories, can contribute to the reconstruction of current Indigenous educational practices and begin to offset the undetected viruses that remain incubating within the people and their current systems. The Creation Story of the Iroquois is one prime example of a multi-faceted story that reflects cultural meaning and affirms spiritual existence throughout its stages. Breaking down the stages as age appropriate curriculum content can perhaps more closely realign early childhood practices with an authentic holistic relationship to a place of origin and spiritual identity.

\section{Indigenous Curricula}

Considering curriculum as culture is a way to attain a holistic understanding of education, not only as planned curricular content, but as experienced or lived in the presence of people and their meanings. (Joseph, 2011, p. 23)

Historically, Indigenous cultural patterns demonstrated living simultaneously with the land and the environment and teaching and learning through cultural, daily, and seasonal repetition, using oral legends and stories as the means of transmission of historical and spiritual doctrine (Armstrong, 1987). The cultural knowledge transmitted throughout one's life is a reflection of the spiritual core of the nation and its ability to facilitate historical governance, ancestral teachings, and the survival of a strong identity preserved for the coming generations (Faries, 2004).

Indigenous education and curriculum were non-existent, in the sense that learning and living was the whole process of education while the curriculum was the environment and the knowledge of the people. However, the evolution of non-Indigenous education promoted through centuries of White Eurocentric doctrine and philosophy has left very little room for the development and acceptance of Indigenous ideologies and knowledge's as relevant curriculum in mainstream academia.

In my interview with Owiso:kon (a grandparent), she talked about how stories are no longer done the same as they used to be. She referred to new technologies and children sitting in front of the television instead of listening to real stories. She said, "Our history and our whole culture is based on storytelling; Whites believe we don't have a history based on fact because there are no written documents proving it." She recalled hearing stories from her grandmother. She said, "Religion hid the stories; it made people not want to tell them anymore."

Indigenous education is based on an experiential form of learning. Ouellette (2011) states that the Dena Tha prefer to learn by personal experience, by watching someone who knows how to do things, and by listening to narratives and stories; therefore, the learning occurs through observation rather than instruction, making the knowledge personal. Looking at curriculum from an Indigenous perspective requires internal cultural knowledge, history, geography, language, and the spiritual knowledge of the people themselves and this should be the primary job of the community at large. Therefore, the education and curriculum is drawn from familiar community contexts that will support and validate the cultural norms through educational endeavors. Simultaneously, it needs to be acknowledged that there would also be the need for nonIndigenous content; teaching about other cultures of the world and the current political or environmental issues through the latest technologies should not be avoided because a "curriculum must take into account the students' current and future needs" (Ouellette, 2011, p. 198). 
For many communities, current curriculum guidelines remain aligned with government criteria. However, the push and demand for interweaving cultural knowledge has grown since the 1970 's, but one of the main challenges is the lack of curriculum development (Ouellette, 2011). The demand is rising; however, "the actual implementation is not occurring on a significant basis" (Faries, 2004, p. 2).

\section{Early Childhood Education}

Early childhood programs were developed based on a community's needs, which mirrored the broader society at large. The initial intent was to cater to working parents and those who went back to school seeking job skills (Greenwood, 2006). Aboriginal Head Start programs were established as on reserve programming to support working mothers and families in need of assistance in early childhood care. In other instances ECE programming provided a support for families in need of early intervention stemming issues of domestic violence, alcoholism, drug abuse, poverty and physical abuse that raised child safety concerns (Greenwood, de Leeuw \& Fraser, 2007).

The root of such problems within many Indigenous communities point directly and indirectly to the longstanding colonial practices of previous and current governing bodies. The emotional, spiritual, psychological, and physical abuse suffered by the children who attended residential schools was profound and the effects are openly visible today. The establishment of Canada's Indian Act affected native communities as well. This act created reserves, controlled governing systems, banned Indigenous customs, and set educational protocols initiated by residential and day school structure (Greenwood et al., 2007).

Bodrova (2003) writes that Vygotsky believed that the social condition of the child was a "basic source" of her and his development. And that other people and the cultural environment of the child do more than modify what is within the child: "They actually shape both the content and the nature of this child's emergent mental functions" (Bodrova, 2003, p. 31). Through Indigenous ways of learning and knowing, children's lives can be profoundly influenced through listening to stories and legends that provide knowledge and spiritual guidance and in turn formulate the intellectual knowledge of a child in those early years.

\section{Early Childhood Education in Kahnawa:ke}

Culturally and historically, early childhood care and daycare services were non-existent in Kahnawa:ke. The largest facility in the community is the Step-by-Step Child and Family Center. They have nine classrooms with children from the age of 18 months to 5 years old. They run an offsite center that enrolls children under the age of 1 year and transfers them to the larger center once they reach 18 months old. Today, early childcare services are in high demand and these early services are relative to the social and cultural changes that have affected most Indigenous communities. In British Columbia, several nations now offer early childhood care services that incorporate parent services and community events that are intended to bring back the trust and relationship of the close knit family care that Indigenous peoples once practiced (Ball, 2004).

The Step-by-Step Child and Family Center is not only a daycare center, but it is also an early childhood and family center. Over the years, families have been invited to participate in school events and community gatherings held at the center. There is a part-time speech therapist and a psychologist available on staff. A dental hygienist makes scheduled visits for the four- and 
five-year-old children. The center also collaborates with Shakotiia'takehnhas Community Services in regard to early interventions whereupon the child must receive early childcare services due to her or him being placed in foster care within the community. The support services available are not only for those in need of intervention, but also, the center offers and promotes events that often include the community and or all families of the children attending the school. Often there are luncheons for working mothers and special luncheons for grandparents and fathers.

\section{Classroom Observations}

I introduce portraits of classroom observations where the recorded stories have been interwoven with the research literature and my insights. Through a qualitative methodological lens, portraits are "the examination of the ways in which the researcher deals with her or his lenses and tools" (Chapman, 2005, p. 34). The researcher's voice is heard "through the central themes" of the data being presented (Chapman, 2005, p. 34).

\section{A Big Book Story}

On May 14, 2013, I entered Sonia's classroom (Classroom 1) during storytelling time. I arrived a bit early as the teacher had asked me not to disturb the flow of the morning routine. The children were somewhat familiar with me being that I had visited twice already to speak with the teacher; her name is Sonia. On one previous visit I sat with a little girl who was finishing her snack. I said hello to her and she immediately invited me to a party at her house. I gladly accepted and she rushed off to the sink washed her hands and discarded her garbage. At the "official" observation, the routine was similar. I entered and said "hello" to the children; they were busy cleaning the remainder of their snacks and readily preparing for circle time. Circle time is the place and time to gather in preparation for the day's routines and to share any pertinent information about guests, events, outings, or personal celebrations and, of course, story time.

On this day, Sonia chose to tell the children the Creation Story using a big book that was nicely illustrated and was laminated and bound with yarn. It was evident that the person who put this big book together had some artistic skill. The drawings were done in colorful markers on large poster boards and resembled professional animated artwork with an Indigenous artist style. The children all sat on the floor in front of Sonia and another teacher sat among the children acting as a second set of hands and eyes and through my observation, it was obviously needed to ensure no "monkey business" was taking place. I sat along the window in order to create a place for my recorder and a secure surface on which to write my notes.

The story began with Sonia recapping the title of the book (The Creation Story) and asking the children what they remembered about the story.

One child replied, "Is that the special one?"

Sonia replied, "Yes, that's the special one."

After reading the first page, the teacher asked, "What do you see?"

The children replied by naming the pictures of the fruit. The children were very attentive to the story and sat in amazement as though they were hearing it for the first time. The half circle 
became tighter as the children moved closer to one another; they looked very relaxed and comfortable leaning on one another trying to get the best possible view of the big book. The children are aged three and one child recently turned four years old. One little girl was distracted by something on the window ledge; then Sonia engaged her with "please pay attention" and called out her name. The little girl looked towards the big book and then returned to her distraction, which was now at the edge of her pant leg.

Culturally and historically elders taught through stories, ceremony, speaking to the children about relationships, and leading by example. The stories reflected a relationship to earth, land, water, animals, and encompassed the most complex understanding of the universe. Listening to stories taught listening skills and helped deepen one's thoughts about community, identity, respect, and spirituality. It was a natural process of education and is rarely used in today's Native societies (Archibald, 2001).

As Sonia read on it was evident that the children knew this story by their eagerness to provide the answers to the questions posed. The story was now at the part where Sky woman falls through a hole in the sky.

She asked, "Where did she go?"

Several children raised their hands in the air and waited to be called on to give their answer. A woman falling through a hole in the sky sounds irrational, mythical, and unrealistic. Gunn-Allan (1992) states that "an American Indian myth is a story that relies preeminently on symbol for its articulation" and "it demands the immediate, direct participation of the listener" (p. 105).

We arrived in the story where birds and water animals offered assistance to Sky woman.

Sonia asked, "What happened to her?"

The children replied, "She's on the turtle's back."

She read on and asked the children "Which animals dove down to the bottom?"

Voluntarily one child shouted, "Otter" then another child repeated, "Otter."

Sonia asked, "What other animals helped her?"

"The muskrat," one child said.

Sonia repeated the question and another child yelled out, "Beaver."

Sonia said "Thank you," and repeated, "The beaver."

"What are they looking for?" she asked.

The children, in unison, shouted out, "Dirt."

The animals were now diving to the bottom of the ocean to retrieve some dirt for Sky woman. In the story, Sky woman uses the dirt to create a land base to walk upon and she plants the seeds and roots that she grabbed at before falling through the hole in the sky. 
The children were engaged and verbally participating in the story. The circle again became closed in and smaller in radius as they slid towards the big book on Sonia's lap. One boy jumped up from the floor and began to demonstrate how Sky woman planted her roots and seeds. He started to move his feet side to side in the motion of a windshield wiper blade of a car.

He stood in place moving his feet and telling Sonia, "This is how she planted."

As he demonstrated how Sky woman plants upon the turtle's back, he began naming vegetables in Kanien'keha (Mohawk). He said, “Ó:nenste, Ononh’òn:sera” (corn, squash).

Sonia responded to his enthusiasm with, "Yes that's right;" then she repeated the vegetables in Kanien'keha (Mohawk). She continued to praise him and added another vegetable, Osahé:ta (beans). These vegetables are also related to Ohèn:ton Karihwatehkwen (opening address), and to the Three Sisters story where the three sisters are Corn, Beans and Squash.

In my interview with Sonia, I asked her about what her goal was on implementing these legends and stories. She replied by saying, "Each legend, depending on which legend you're reading, has a lesson, right! There's something behind each story/legend; there are teachings; that's why you use them; they're not just making them up; there's a reason why we use them" (Interview, April, 22, 2013).

\section{Sky Woman's Fall}

Oral recitations of the Creation Story, in other words, not only describe the origins of the world but also perpetuate the moment of Creation in the present. (Parmentar, 2010, p. xxxv, xxxvi)

On May 28, 2013 I walked into Stephanie's class (Classroom 2) for observation number two. The children were all seated and the assistants were preparing to sit alongside the children at circle. The floor was crowded with little tiny people and a couple of big people. These children's ages ranged from 18 months to three years old. In a prior conversation, Stephanie mentioned that the children who are three, or who will be turning three, move up to the next classes, for instance to Sonia's class.

I situated myself behind the circle of children, placing my recorder on a small shelf in front of me. I was so amazed at how the children were all ready and waiting to begin. The class began with Ohèn:ton Karihwatéhkwen, the opening address. They used a small booklet of pictures that identified with each passage. This booklet is a miniature version of the large picture cards drawn by a local artist. Each child took a turn to hold up the small picture as the others recited the passage that identifies each picture: "Teiehtinonhwerá:ton ne kahnekarónnion" (We offer our thanksgiving to all the waters).

Stephanie told the Creation Story orally to the children. There was no big book or colorful, store-bought storybook to show the children. Instead there was a large box on the floor that was painted a turquoise blue with imitation grass glued to the top and what looked like a handmade tree decorated with colorful objects. I gathered from my own knowledge of the story that the objects represented the fruit and foods available from the tree of life in the story. Inside the box there was a dark blue paper glued to the surface that created an ocean-like representation. As she began the story she asked the children if they knew who the characters were (the stuffed dolls). 
She answered her own question by saying, "It's Sky woman," then asked, "What did she have in her belly?"

One child answered, "A baby."

"Yes, a baby," Stephanie answered back. As she moved along she explained that Sky woman became very hungry and wanted strange foods to eat and she asked her husband to get her some bark from the tree of life. He refused her request and she became even more persistent. Finally, he helped her to the tree and she began to dig beneath it.

Stephanie used the characters (stuffed dolls) to demonstrate Sky woman digging beneath the tree and she held the husband (other stuffed doll) next to her as he told her not to dig so deep.

She said to the children "Guess what? She lost her balance and she started to..."

Two of the children answered, "Fall" in a loud and prolonged tone.

Stephanie demonstrated Sky woman (doll) falling to the water (the bottom of the box). As she (the doll) was falling, Stephanie pretended to be Sky woman and hollered out "Ahhh" as Sky woman fell through the hole in the sky. landed?'

She continued to describe Sky woman's fall and then asked, "Remember where she

In unison, two children answered, "Turtle's back."

Sky woman was now on the turtle's back and Stephanie told the children that she was scared and that she missed her husband. She said that Sky woman told the animals, "I have nothing to eat; what am I supposed to do? I have roots and seeds from the tree of life but nowhere to plant them. I need some dirt, o'ken:ra, then I can plant my roots and seeds." Stephanie used some Kanien'keha (Mohawk) words in the story, such as O'kèn:ra-dirt, Ken'niiohontéhsa-strawberry. She continued on, telling the children that the animals offered to swim down to the bottom of the ocean to get Sky woman some dirt.

She told the children that the otter was the first to try and he was not successful, then the muskrat tried and he was not successful, and then beaver tried, and she said, "Beaver came up from the bottom of the ocean and had some dirt in his paw and said to Sky woman, 'here you go." She then explained that Sky woman took the dirt and began to pour it over the turtle's back and then she began to dance and sing some songs she remembered. She reminded the children that when Sky woman fell she grabbed onto some plants, roots, and seeds such as Indian tobacco, strawberry, and the Three Sisters.

She told the children that the land began to grow and eventually that it became Mother Earth. She reminded them that they just finished giving thanks to her (Mother Earth) today, and said, "Isten'a tsi iohontsa:te-our mother the earth."

This version of the Creation Story is adapted and as in many stories, teachers and storytellers will adapt a story to the appropriate level of their students and listeners. Adaptation is one of the traits in oral legends and storytelling. The narrator could create many twists and turns throughout the story in order to appease the audience. 


\section{A Portrait Discussion}

The action of storytelling is in itself a teaching tool; it helps teach listening skills, and deepen one's thoughts about community, identity, respect, and spirituality (Archibald, 2001). Maxine Greene says, "We identify ourselves by means of memory" and memory helps us to "compare the stories of our lives" (as cited in Strong-Wilson, 2007, p. 116).

Through examination of my research data it became apparent that legends and storytelling played a significant role at the Step-by-Step Early Childhood and Family Center and are believed to be a cultural component needed for the revival and reconnection to a Kanien'kehá:ka identity. The legends told here have definitely been told before. As I observed the children listening to the stories, I witnessed eagerness and amazement projecting through their faces. I also heard memories and knowledge voiced by the children on story parts and story characters.

Gail (administrator of Step-by-Step) is a former early childhood educator with many years experience and has been a significant part of the cultural development at the center. She expressed similar thoughts about the importance of teaching the Creation Story, the Great Law of Peace and the Ohèn:ton Karihwatéhkwen (opening address), saying, "The culture, language and stories are related to who we are, it explains our culture and what it means to us and it should all have a place in our education system."

These portraits helped me see that the art of storytelling remains a powerful and necessary tool in early childhood education. It helps teach the children about life and nature, and morals and values that not only resonate with Kanien'kehá:ka identity, but also project themselves in every aspect of living as a human being on Mother Earth, instructing care for the earth, waters, animals, plants, foods we eat, and medicines. They teach about the stars and the moon, the clan system, the relations between spirit and humans; they teach respect for the universe as a whole.

These stories are meant to penetrate the soul's knowledge, and as one grows and ages the memories and teachings reflect outward back into the world around, creating a physical, emotional, and spiritual connection that supports life's journey. Each child who raised his or her hand and shouted out answers or names of characters and animals demonstrated and reflected their own memories of stories told to them through oral transference and in some instances, a big book. I saw that the books were not so much part of the story. They were props or visuals for the children. The teachers themselves told the stories through their own memories and knowledge, demonstrating the highs and lows, the suspense and wonder, the flying, the falling, the calling out for help, and the emotions portrayed by the characters.

Each portrait demonstrates its own story within, a story of teacher as cultural advocate and learner and the children as cultural learners and knowledge holders. Every story told can generate new images and reinforce the old ones. King (2003) writes in just about every chapter of his book: "The truth about stories is that that's all we are" (p. 2).

At some point in our lives we will all look back at our own stories and the stories told to us by tracing a semi-circle. The semi-circle will soon become a full circle and here is where we will finally understand that we are all but a vessel filled with stories that make up our lives, identities, languages, and beliefs. 


\section{Culture as Curriculum}

My classroom observations showed that storytelling is alive and well in the classrooms at Stepby-Step and that storytelling comprises a significant part of daily school culture, which in turn pours out into the daily culture of the children. The children's physical and verbal interactions gathered during classroom observations provide evidence that stories live through the people. Storytelling brings their imaginations to life - to real life - this was gleaned in interviews with community members: the parents and grandparents of the children.

In each interview I asked the participants if they felt or believed that legends and storytelling are an important part of Kanien'kehá:ka culture and identity. All the participants answered yes to the question, stating various reasons why they feel and believe it is important.

Two parents also commented on the Creation Story and what they remembered from their own schooling: Tina (parent) talked about the Creation Story: "I only remember bits and pieces but what I do remember is that it teaches our history, our culture and where we come from." Tekaronhiahkhwa (parent) also remembered learning the Creation Story in school. She explained that the creation story is so long that it's too long and too much for young children; it always needs to be modified for the age level. They don't teach it in high school but she believes they should because in high school they can make more sense of it.

Throughout the interviews there were mixed emotions from all the participants. What was profoundly moving to me was that all of these women, including the teachers, shared the same emotional strength and deep feelings around the important role of cultural stories and legends.

In my interview with Tekaronhiahkhwa (parent) she explained why she felt so strong about a curriculum based on cultural stories and practices. She said,

We need to get back to our teachings and learn how to be thankful; if we don't remember to be grateful, we're going to lose that aspect of our culture (she began to cry) and I don't want my children to have to go through what I went through: that feeling of disconnectedness and not knowing where you belong.

\section{Conclusion and Recommendations}

I will conclude with some thoughts and ideas on how legends and storytelling can act as a guiding tool for a reevaluation of education in Kahnawa:ke. I recommend that we begin from the ground up, just as we recite Ohèn:ton Karihwatéhkwen (opening address) and as the Creation Story continues to teach, beginning with the earth, the grass, the bugs, to the water, the trees, the animals, the birds, the thunder, the stars, the sun, the moon, and the Creator.

Takwanonhwerá:ton, Iethi'nisténha ohóntsa, ohente'shón: 'a, otsi'nonwa'shón:'a, ohneka'shón:a', okwire’shón:'a, kontírio, otsi'ten'okón:'a, ratiwé:ras, iotsistohkwa'shón:'a, tiohkehnéhkwa karáhkwa, ahsonthenhnéhkha karáhkwa tánon Tetia'tison.

At the very start we should offer teachers adequate cultural training (knowledge), free of judgment, and language courses in and out of the workplace. (Band council employees are offered free language courses during their lunch hour.) The focus of these teachings should come 
from our stories and legends with further development linked to Kanien'kehá:ka spirituality and incorporated into classroom activities and community and school culture. This training/learning should be extended system wide, meaning the whole system, including secretaries, maintenance workers, substitute staff, resource people, and all administration should also participate. Scheduled appropriately, non-Native teachers should take part in this training as well. They are part of the system and a significant part of our children's daily lives.

I recommend curriculum development through collaboration of elders and cultural knowledge holders through smaller group sessions and periodical feedback from parents and elders. I also recommend that there be political support, not as a guiding force but as an advocate in relation with INAC. Of course this person (or these persons) would also be involved in all cultural training and language courses. Some core ideas for curriculum development could stem elder's collaboration and parent feedback.

Through my findings, I also conclude that the desire for a culture-based education may be a key component for retrieving the connection once felt through knowing the true meaning of legends and stories. The two young mothers interviewed both shared that they wanted to learn more but did not have an avenue open to them at this time. This reveals that there should be more open classes for young mothers and scheduled at their convenience. Maybe a variety of time slots and days of the week could also be offered for community members, young mothers, and also young adults.

My final recommendation is that we as Indigenous scholars continue working toward recognition and validity of our culture as ways of knowing, teaching and learning. It is my dream to have an all-Indigenous curriculum course designed for all educators, using stories and legends as the foundation of development. It is my hope that this research will in some way contribute to a new beginning through a reevaluation of the Kahnawa:ke education system and, therefore, bring that shining pride back to our children's faces and hearts.

Nià:wen tánon tho kati naiohton nonkwa’nikón:ra—Thank you and now our minds are as one. 


\section{References}

Alfred, T. (1999). Peace power righteousness. An Indigenous manifesto. Don Mills, ON: Oxford University Press.

Alfred, T. (2010, May, 13). From noble savage to righteous warrior: Regenerating and reinscribing Indigenous presence. Retrieved from https://youtube/8ZfGAqdlJmE

Antone, E., \& Córdoba, T. (2005, fall). A wholistic approach to re-storying Aboriginal literacy: Literacies and Community. \#6 , 9 - 11. Retrieved from http://casaeaceea.ca/ casae/sites/casae/archives.cnf2005/2005onlieProceedingsCAS2005ProAntone.pdf

Archibald, J. (2001). Editorial: Sharing Aboriginal knowledge and Aboriginal ways of knowing. Canadian Journal of Native Education, 25(1), 1 - 5.

Armstrong, J.C. (1987). Traditional Indigenous education: A natural process. Canadian Journal of Native Education, 14(3), 14 - 19.

Ball, J. (2004). Early childhood care and development programs as hook and hub: Promising practices in First Nations communities. Victoria, BC.

Brenner, E. M. (2006). Interviewing in educational research. The handbook of complementary methods in education research (AERA) (pp. 357 - 370). Santa Barbara CA: University of California.

Creswell, J. W. (2009). Research design. Qualitative, quantitative, and mixed methods approaches. Thousand Oaks, CA: Sage.

Chapman, T. K. (2005). Expressions of "voice" in portraiture. Qualitative Inquiry, 11(1), 27 - 51. doi:10.1177/1077800404270840

Duryea, LeBaron. M. \& Potts, J. (1993). Story and legend: Powerful tools for conflict resolution. Mediation Quarterly, 10(4), 387 - 395. doi:10.1002/crq.3900100407

Faries, E. J. (2004). Research paper on Aboriginal curriculum in Ontario. Chiefs of Ontario. Retrieved from: http://www.chiefs-ofontario.org/sites/default/files/files/A\%20Research\%20Paper\%20on\%20Aboriginal\%20C urriculum $\% 20 \mathrm{in} \% 20$ Ontario.pdf

Friesen, J. W., \& Friesen, V. L. (2007a. March 15 - 17). Storytelling makes a comeback: Aboriginal contributions to the teaching/learning process. A Paper presented at the Eighth Annual Conference of the Indigenous Woman's Conference. Trent University, Peterborough, ON. Retrieved from http://tmkdj.com/static.drsfriesen.com/1resources/2007_03_story_tellling.pdf

Friesen, J. W., \& Friesen, V. L. (2007b, February). Inculcating Indigenous knowledge and spirituality: A Siksika (Blackfoot) theory of learning. Electronic Journal. Retrieved from http://tmkdj.com/static/drsfriesen.com/1/resources/2007_02_inculcating.pdf

Greenwood, M. (2006). Children are a gift to us: Aboriginal-specific early childhood programs and services in Canada. Canadian Journal of Native Education, 29(1), 12 - 28. 
Greenwood, M., de Leeuw, S., \& Fraser, T. N. (2007). Aboriginal children and early childhood development and education in Canada: Linking the past and the present to the future. Canadian Journal of Native Education, 30(1), 5 - 18.

Grove, W. R. (1988). An analysis of the constant comparative method. Qualitative Studies in Education, 1(3), 273 - 279. doi:10.1080/0951839900030105a

Gunn-Allan, P. (1992). The sacred hoop. Recovering the feminine in American Indian traditions. Something sacred going on out there: Myth and vision in American Indian literature (pp.102 - 117). Boston, MA: Beacon Press.

Haig-Brown, C. (1988). Resistance and renewal. Surviving the Indian residential school. Vancouver, BC. Arsenal Pulp Press.

Hill, J. C. K. (2002). Editorial-Indigenous education: Ways of knowing, thinking, and doing. McGill Journal of Education; 37(3). 281 - 291.

Ho‘omanawanui, K. (2010). Mana Wahine, education and nation-building: Lesson from the epic of Pele and Hi 'iaka for Kanaka Maoli today. Multicultural Perspectives, 12(4), 206 - 212.

Joseph, P. B. (2011). Understanding curriculum as culture. (2 $2^{\text {nd }}$. ed.) In P. B. Joseph (Ed.), Cultures of curriculum ( $2^{\text {nd }}$ ed., pp.23 - 35). New York, NY: Routledge.

Kanu, Y. (2006). Reappropriating traditions in the postcolonial curricular imagination. In Kanu, Y. (Ed), Curriculum as cultural practice: Postcolonial imaginations (pp. 203 - 222). Toronto, ON: University of Toronto Press.

King, T. (2003). The truth about stories. A Native narrative. Dead Dog Café Productions and the Canadian Broadcasting Corporation.

Kirkness, V. J. (1995). Aboriginal peoples and tertiary education in Canada: Institutional responses. The London Journal of Canadian Studies, 11, 28 - 40.

Kovach, M. (2005). Emerging from the margins: Indigenous methodologies. In L. Brown \& S. Strega (Eds.), Research as resistance: Critical Indigenous, and anti-oppressive approaches. Toronto, ON: Canadian Scholars Press/Woman's Press.

Lutz, H., \& Moritz-Arndt, E. (1995). First Nations literature in Canada and the voice of survival. The London Journal of Canadian Studies, 11, 60 - 76.

McKeough, A., Bird, S., Tourigny, E., Romaine, A., Graham, S., Ottmann, J., \& Jeary, J. (2008). Storytelling as a foundation to literacy development for Aboriginal children: Culturally and developmentally appropriate practices. Canadian Psychology/Psychologie canadienne, 49(2), 148-154. Doi10.1037/0708-5591.49.2.148

Ouellette, R. F. (2011). Evaluating Aboriginal curricula using a Cree-Métis perspective with a regard towards Indigenous knowledge. (Master's Thesis). University of Laval. http://www.theses.ulaval.ca/2011/27621/27621.pdf

Parmenter, J. (2010). The edge of the woods. Iroquoia, 1534 - 1701. East Lansing: MI: Michigan State University Press. 
Pence, A., Rodriquez de France, C., Greenwood, M., \& Pacini-Ketchabaw, V. (2007).Indigenous approaches to early childhood are and education Introduction. The Canadian Journal of Native Education, 30(1), 1 - 4.

Rains, F. V., Archibald, J., \& Deyhle, D. (2000): Introduction: Through our eyes and in our own words. International Journal of Qualitative Studies in Education, 13(4), 337 - 342

Smith, L.T. (1999). Decolonizing methodologies: Research and Indigenous peoples. Londodon,UK: Zed Books. Copyright 2012 by Author.

Strong-Wilson, T. (2007). Moving horizons: Exploring the role of stories in decolonizing the literacy education of White teachers. International Education, 37(1), 114 - 131.

Wallace, P. (1994). White roots of peace. The Iroquois book of life. Santa Fe, NM: Clear Light.

Wilson, S. (2001). What is an Indigenous research methodology? Canadian Journal of Native Education,25(2), 175 - 179.

Wilson, S., \& Wilson, P. (2002). Editorial: First Nations education in mainstream systems. Canadian Journal of Native Education, 26(2), 67 - 68. 